\title{
An Archaeological Survey of Proposed Seismic and Pipeline Routes at the Chaparral Wildlife Management Area, Dimmit and La Salle Counties, Southern Texas
}

A. Joachim McGraw

Follow this and additional works at: https://scholarworks.sfasu.edu/ita

Part of the American Material Culture Commons, Archaeological Anthropology Commons, Environmental Studies Commons, Other American Studies Commons, Other Arts and Humanities Commons, Other History of Art, Architecture, and Archaeology Commons, and the United States History Commons

Tell us how this article helped you.

This Article is brought to you for free and open access by the Center for Regional Heritage Research at SFA ScholarWorks. It has been accepted for inclusion in Index of Texas Archaeology: Open Access Gray Literature from the Lone Star State by an authorized editor of SFA ScholarWorks. For more information, please contact cdsscholarworks@sfasu.edu. 


\section{An Archaeological Survey of Proposed Seismic and Pipeline Routes at the Chaparral Wildlife Management Area, Dimmit and La Salle Counties, Southern Texas}

Creative Commons License

(c) (1) (9)

This work is licensed under a Creative Commons Attribution-NonCommercial 4.0 International License 


\section{AN ARCHAEOLOGICAL SURVEY OF PROPOSED SEISMIC AND PIPELINE ROUTES AT THE CHAPARRAL WILDLIFE MANAGEMENT AREA, DIMMIT AND LA SALLE COUNTIES, SOUTHERN TEXAS}

A. Joachim McGraw 

Genter for Archaevloyleal Tesearch The University of Texas at San Antonio San Antonid, Texas 7828 . 

AN ARCHAEOLOGICAL SURVEY OF PROPOSED SEISMIC AND PIPELINE ROUTES AT THE CHAPARRAL WILDLIFE MANAGEMENT AREA, DIMMIT AND LA SALLE COUNTIES, SOUTHERN TEXAS

A. Joach im McGraw

Texas Antiquities Committee Permit No. 513

Thomas R. Hester, Principal Investigator

Center for Archaeological Research The University of Texas at San Antonio Archaeological Survey Report, No. 165 
The following information is provided in accordance with General Ru 1 es of Practice and Procedure Chapter 41.11 (Investigation Reports), Texas Antiquities Committee:

1. Type of investigation: archaeological survey;

2. Project name: Chaparral Wildlife Management Area;

3. Counties: Dimmit and La Salle;

4. Principal Investigator: Thomas $R_{0}$. Hester;

5. Name and location of sponsoring agency: Lightning $0 i 1$ Company, San Antonio, Texas;

6. Texas Antiquities Committee Permit No. 513;

7. Published by the Center for Archaeological Research, The University of Texas at San Antonio, San Antonio, Texas $78285-0658,1987$.

A 7 ist of publications offered by the Center for Archaeological Research can be obtained by sending $\$ 1.00$ to the Center for Archaeological Research, The University of Texas at San Antonio, San Antonio, Texas 78285-0658. 


\section{ABSTRACT}

An intensive archaeological survey was conducted along proposed pipel ines and seismic 1 ines by personnel from the Center for Archaeological Research. The University of Texas at San Antonio, in the Chaparral Wild 1 ife Management Area, located in Dimmit and La Salle Counties. Four prehistoric sites were recorded, and a surface collection was made at each site. Due to the 1 ack of diagnostic materials recovered and the severe erosion of the site areas, no further work is recommended for any of these sites. 
TABLE OF CONTENTS

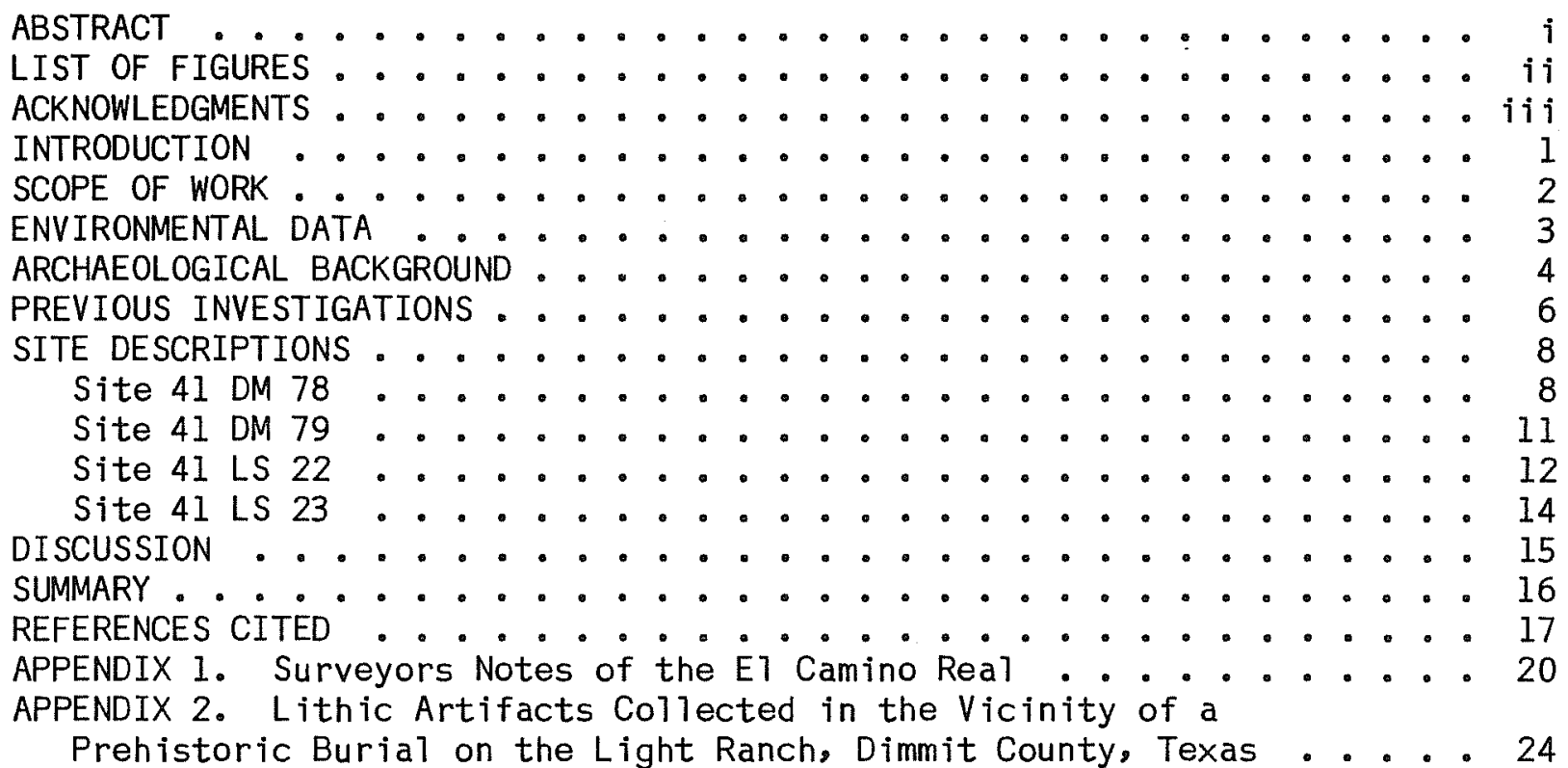

LIST OF FIGURES

1. Location of Archaeological Sites Along Proposed Seismic and Pipeline Routes ................. 9

2. Artifacts Recovered from Sites 41 DM 78, 41 DM 79, 41 LS 22, and 41 LS $23 \ldots \ldots \ldots$ 
ACKNOWLEDGMENTS

A "thank you" is extended to the Texas Parks and Wildlife Department and the Lightning $0 i 1$ Company, especial1y Mr. Walter Scott Light, for their courtesy and cooperation during this archaeological survey work. I appreciate the help of the Center for Archaeological Research office staff, especially Mary Lou ElTis, typist, and Sharon Quirk, editor. 



\section{INTRODUCTION}

During August 8-10, 1985, personnel from the Center for Archaeological Research (CAR). The University of Texas at San Antonio (UTSA), conducted an intensive archaeological surface survey along proposed pipeline and seismic lines within the Chaparral Wildlife Management Area, owned by the Texas Parks and Wildlife Department, located in southeastern Dimmit and western La Salle Counties. The cultural resources investigations were conducted in response to the standards and requirements of the National Historic Preservation Act of 1966, as amended. Assessments of sites identified during this project were based upon their potential for nomination to the National Register of Historic Places and as a State Archeological Landmark.

The intensive survey work was initiated following approval of work in a letter dated June 26, 1985, from Mr. Walter Scott Light of the Lightning $0 i 1$ Company and Jack Eaton, associate director of the CAR-UTSA. Principal investigator for the project was Dr. Thomas R. Hester, director of the CAR. Project personnel consisted of research associate A. Joachim McGraw and technical staff assistants Rodney Krehbiel and Cecil Peel. Following completion of the field work, a preliminary records and archival review were completed of related data from the Texas Archeological Research Laboratory, Austin; the John Peace Memorial Library (UTSA); the Daughters of the Republic of Texas Research Library at the Alamo; and the records and collections of the Witte Museum, San Antonio. Published and unpublished information on flle at the CAR 1 aboratory was reviewed as background for nearby site descriptions and assessments.

Field work consisted of intensive pedestrian surveys and horseback travel along the proposed seismic 1ines. All seismic and pipeline routes were clearly marked by surveyors stakes and flagging tape. Although it was estimated that only a corridor width of $20 \mathrm{~m}$ at the maximum would be impacted along the lines, actual field survey included an approximate $100 \mathrm{~m}$ width to allow for some future flexibility along the routes, given the variability of terrain and potential avoidance of recorded sites. Two proposed seismic lines and one pipeline were surveyed for a total distance of ca. $27 \mathrm{~km}$.

Four sma11 temporary prehistoric occupation sites were identified along or adjacent to the surveyed 1ines. A discussion of these sites is presented in the Site Descriptions section of this report. No further work is recommended at any of these locations because of the 1 imited amount of artifactual evidence, the lack of significant diagnostic materials or features, and the extensive damage of site areas by natural erosion.

Additionally, following the completion of pipeline and seismic line inspections, and as a courtesy to both the Texas Parks and Wildlife Department and the Lightning $0 i 1$ Company for their hospitality and cooperation, attempts were made to 1ocate a smal1 19th-/early 20th-century family cemetery in the northeastern portion of the management area. Identification of the cemetery location had been difficult in recent times due to the lack of specific data and the deterioration or loss of markers which once identified the site. Descriptions of the site area and comparisons with topographic and aerial maps. led Center personnel to the projected location; however, systematic transects at ca. 40-m intervals 
across the area did not identify the cemetery. A small prehistoric site was found and recorded at this location. Since this site is located beyond the impacted area of the present scope of work, and no significant features were noted, site data from this location has been reported separately to the Texas Archeological Research Laboratory, Austin.

\section{SCOPE OF WORK}

The investigation of portions of the Chaparral Wildiife Management Area consisted of two primary objectives: (1) a 100\% intensive field survey of potentially impacted areas; and (2) a review of background prehistoric and historic data of the area. During the field work, a wider area than necessary was intentionally surveyed to allow for some future flexibility during line construction. During the survey, distinctive topographic features adjacent to the proposed lines were inspected to identify possible patterns of prehistoric remains in the local area. Given the limited amount of archaeological information known for the region generally and Dimmit County specifically, this methodology was considered critical for accurate assessments of newly identified sites.

Field methodology was directed toward a systematic and effective identification and assessment of cultural resources. Actual survey work was accomplished by a team of two people. As vegetation and thorny brush permitted, the survey corridors were kept aligned as close as possible to the previously placed flagged markers indicating the proposed routes. Personnel were spaced at $25-\mathrm{m}$ to $50 \mathrm{~m}$ intervals, depending upon topography and ground cover. Each individual, in addition to carrying assorted personal equipment, was also required to carry a compass, canteen, machete, topographic map with the survey routes clearly marked, a snake bite kit, and such common survey items as flagging tape, field forms, collection bags, etc. All site locations were recorded on standard site survey forms to describe site data as required by the Texas Historical Commission and the Texas Archeological Research Laboratory. Austin. Whenever possible located sites were revisited to review the accuracy of the site description, dimensions, and location.

A review of available published and unpublished data was undertaken not only to establish the general cultural background but to identify elements that may have influenced the development of the study area. For example, red granite highway markers indicate the Spanish colonial (Lower Presidio) El Camino Real once traversed, the general, if not the immediate vicinity of, the study area. Efforts were made to reestablish or at least identify the location of this old roadway (see Discussion section of this report) in the locality.

Research was directed toward a basic data-gathering strategy that sought to identify and compare newly identified sites with the types, cultural remains, and patterns noted elsewhere in this portion of southern Texas. It was thought such an approach would be both useful and appropriate, given the study area's proximity to other areas archaeologically investigated (see Archaeological Background section). 
Collected materials were 1 imited to diagnostic or other significant artifacts. A 100\% sample of 1ithic debris was collected from a $25-\mathrm{m}^{2}$ area of each site location to, at least partial1y, determine the types of worked stone, characteristics, and the extent of utilized and modified 1 ithic debris. Although basically a judgmental sampling strategy, this collection. by recognizing its biased 1 imitations, still offers an effective method of more closely identifying past site activities and functions. Numerous erosional features throughout the area, often in excess of $25 \mathrm{~cm}$ deep, and exposures at roadcuts, senderos, and slope washes contributed to observations of site condition and the extent and depth of cultural deposits.

The archaeological field methods and research efforts for this work followed Hester, Heizer, and Graham's (1975) Field Methods in Archaeology and the Council of Texas Archeologists! (CTA 1981) performance standards. All collected materials, field notes, photographs, and other site information are currently on file at the CAR 1 aboratory.

\section{ENVIRONMENTAL DATA}

Located $\mathrm{ca} 120$ miles southwest of San Antonio, the study area is situated in the rolling, mesquite-covered plains of southeastern Dimmit County and the western margins of La Salle County. Honoring Philip Dimitt of the Texas Revolution, the county's name was originally misspelled when it was created from portions of Bexar. Maverick, Uvalde, and Webb Counties. Although created in 1858, Dimmit County was not organized until 1880. The county today is noted for its agribusiness and $0 i 1$ and gas production.

Geological1y, Dimmit County is characterized by exposures of Quaternary deposits with more recent materials exposed in a southward trend toward the Gulf Coast. The geological history of Tertiary and Quaternary deposits in southern Texas is related to extensive oscillations of the Gulf sea coast in past times as well as massive sediment deposits from large, ancient streams. The surface geology of the eastern three-quarters of the county is composed of a marl zone over an iron-bearing clay zone 10-25 miles wide known as the Nacogdoches Cuesta.

The Carrizo Sand formation composes the basis for the county water source and also functions as a major underground water resource over much of southern Texas. Originating as a continental deposit 7 aid down by streams that dropped massive sand load on a coastal plain. these Eocene deposits are thought to be related to ancient floods that transported large quantities of unconsolidated sands to the present coastal plain (Sellards, Adkins, and Plummer 1958:612-619). The average permeabi 1 ity of the Carrizo Sands has been calculated in excess of $24,000,000$ gallons per day for the pump districts of Zavala and Dimmit Counties (ibid.).

Soils in the vicinity of the study area are related to fossil outwash plains and old stream terraces. These deposits create a variety of soil types adjacent to mainstream tributaries such as San Roque Creek, where the soil is formed from sandy, clayey, upland materials. The margins of the Nueces River drainage (including the study area) are characterized by severely eroded marl 
hills in uplands that merge into alluvial terraces of sand, clay, or black soil along tributary drainages (Nunley and Hester 1966:235).

The hydrology of the study area and the eastern portion of Dimmit County in general is dominated by the Nueces River drainage which flows southward. Just west of the study area, San Roque Creek, a major tributary of the Nueces River, flows intermittently northeastward. The western margins of the county are drained by tributaries of the Rio Grande (Nun 1ey and Hester 1966:235236). A tertiary, intermittent drainage, Sage Creek, bisects the study area and eventual 1 y joins the Nueces River ca. $12 \mathrm{~km}$ north of the study area. A detailed discussion of post-Quaternary paleoenvironmental development of the Nueces River system in the area is presented in McGraw and Knepper (n.d.).

While further detailed data is beyond the scope of this report, it should be noted the physiographic character of the study area and region have changed extensively since the late Pleistocene, and such developments have accounted for, as yet, little understood shifts of drainage patterns and biotic communities. The reader is referred to Nunley and Hester (1966), Hester (1978a), Montgomery (1978), and McGraw and Knepper (n.d.) for further details on the environmental background of the area.

Dimmit County 1 ies in the northwestern portion of the Tamaulipan Biotic Province, an environmental community that is characterized by a semiarid climate, low-growing thorny brush and mesquite, prickly pear, and other cacti. Historically, the area was known as a plain, but recent brush invasions have given it the appearance of a brush1 and (McGraw and Knepper n.d.). The chaparral of southern Texas has been described by some as containing "the worst brush in the United States of America" (Dobie 1929:201). Fol lowing current field work, it was obvious the biotic community has remained stable for at least the 1 ast 50 years (see also Inglis 1964 and Hester 1980 for more detailed discussions).

\section{ARCHAEOLOGICAL BACKGROUND}

The archaeology of southern Texas is divided into three major cultural divisions that represent the postulated, changing adaptive strategies of a long time span of hunter-gatherers across the region. Few attempts have been made at refining these broad divisions into formal cultural-processual or chronologically defined phases, primarily due to the large gaps of data in the archaeological record.

A Paleo-Indian period (ca. 9200-6000 B.C.) is known to have occurred throughout southern Texas at the terminal Pleistocene Epoch as far-reaching climatic changes dramatically altered environmental conditions throughout North America. While not wel 1 understood culturally, evidence from this early period includes a series of fluted projectile points such as Clovis (ca. 9200 B.C.) and Folsom (ca. 8800-8200 B.C.). Neither related complex has been we 17-defined regionally, and major variations of the diagnostic point types (and related complexes?) exist in Texas. Paleo-Indian points that date after 8200 B.C. are also found in scattered contexts throughout the area (Hester 1980a:134-145): Golondrina (7000 B.C.), P1ainview (8200 B.C.), Scottsbluff (6500 B.C.), and Angostura (6500-6000 B.C.). These projectile 
points and their related cultural complexes are thought to have been associated with a climatic transition that had profound effects on the regional biota as well as the adaptive strategies of hunting and gathering groups.

Following the significant environmental changes that marked the end of the Pleistocene Epoch, hunting and gathering cultures developed throughout North America. This period, termed the "Archaic" (beginning regionally about 6000 B.C.), refers to a series of preagricultural aboriginal cultures whose subsistence patterns revolved around a hunting and foraging 1 ife style. Regional1y, Archaic sites are found in a variety of physiographic contexts and, because of the length of prehistory involved, dominate the types of prehistoric sites found throughout this area. Chipped stone artifacts from these sites are characterized by primarily triangular and subtriangular unstemmed points, with some corner or side-notched points. A variety of bifacial and unifacial stone tools are also noted in 1 ithic collections from this period throughout the region. Common Archaic chipped stone artifacts found in Dimmit County are Tortugas, Abasolo, Catan, Matamoros, Langtry, and Shumla projectile points and a distinctive local type, Carrizo. Significant Archaic sites of the county are 41 DM 13 (Bowman Ranch), 41 DM 14 (Hester Farm), 41 DM 27 (Garcia site), 41 DM 27, 41 DM 40 (Buckhorn Ranch), and 41 DM 49 (Hester 1984:3).

By about $A_{0} D_{0}$ 1000, although the regional patterns of hunting and gathering continued, distinctive changes occurred in the material cultures of these past peop 1es. Known as the Late Prehistoric (A.D. 1000-European contact), the introduction of the bow and arrow, the use of small end scrapers and flake drills, and a widespread blade technology are characteristic of this period. Small arrow points such as Perdiz, Scallorn, Zavala, and a series of triangular points are commonly found at Late Prehistoric sites in the Dimmit County area and other portions of southern Texas ( 1 bida).

Late Prehistoric occupation sites are usually located adjacent to modern stream or river channels throughout the region. Hester (1980b:130) suggests that some forms of arrow points found at Late Prehistoric sites indicate cultural contemporaneity; a situation distinct from the Late Prehistoric sequence that is defined for central Texas. Such dicotomies of the archaeological record point out the distinctive nature of southern Texas archaeology. The reader is referred to Hester (1980a, 1980b) and Hal1. Black, and Graves (1982) for further discussions of the area's prehistory.

Historic Indian groups of southern Texas are represented by at least seven distinct linguistic associations (Hester 1980a:39); most are intrusive into the region. Those groups regarded as indigenous to the area, various Coahuilteco 1 anguage related groups, are known to have exploited the natura 1 resources across most of southern Texas. However, because of only fragmentary documentary evidence and descriptions, it is difficult, if not often impossible, to identify most of these peoples in any detail. The reader is referred to Campbel1 (1975), Mallouf, Baskin, and Killen (1977), Campbel 1 and Campbel1 (1981), Hal1, Black, and Graves (1982), and McGraw and Hindes (1987) for further summaries of Coahuilteco, Athapaskan (Apache), Shoshonean (Comanche), and other Historic Indian groups of southern Texas. 
The early development of what was to become Dimmit County was related to the Spanish colonial road system established across Texas in the 17th century. The El Camino Rea 1, as it became known, served as the major roadway in an economic and transportation network that sought to tie the scattered outposts of the Spanish frontier into a loosely connected but politically viable system of missions and presidios. Regardless of its success or failure in its strategic capacity, the roadway did, however, become a major artery for trade across Texas long after the decline of Spain's influence in the New World. The road network was still utilized well into the 19th century, although the regional transportation system had greatly expanded and diversified. The connection between the historical roadway and the study area is commented on in the Discussion section of this report. The reader is referred to Tidwel1 (1984) for a more detailed discussion of the early history and development of Dimmit County.

\section{PREVIOUS INVESTIGATIONS}

The first historical description of the study area and its vicinity comes from the early descriptions of Sol9s (1931) in 1683 and Friar Morfi in 1778. The latter traveled on the El Camino Real in the vicinity of the Aguaje de San Roque on his way eastward across Texas; he described the location of the Aguaje de Santa Catarina (Santa Catarina Pool), San Roque Creek, and other loca 11 andmarks. Berlandier, the famous 19th-century natural ist who traveled through Texas and Mexico in the early 1800s, al so passed through present-day Dimmit County but apparent7y traveled the upper Presidio Road in the vicinity of Lake Espantosa (not the lower Presidio, Old San Antonio, or El Camino Real adjacent to the study area).

As early as 1915, V. N. Zivley (1916), a civil engineer, traveled through the study area while surveying the location of the El Camino Real from Pendleton's Ferry on the Sabine River to Paso de Francia on the Rio Grande. Sponsored by the Daughters of the American Revolution, Ziv ley erected 123 markers or posts at approximately five-mile intervals along the route that he had tediously remapped. Zivley established post \#117 along San Roque Creek (a few miles west of the study area), traced the colonial road northeast, and marked post \#116 ca. five miles west of where Dimmit and La Sal le Counties meet (see Appendix 1). A granite marker is located on Highway 133 near the entrance to the W. S. Light Ranch headquarters and another, ca. five miles east, faces the game fences of the Chaparral Wildlife Management Area.

It is assumed these markers correspond to Zivley's original markers \#116 and \#115, but the scope of current studies precludes more definite descriptions. Perhaps Zivley's route of the El Camino Real may pass through the northwestern margins of the management area adjacent to the Light Ranch. The memoirs of P. Tum 1 inson (1980:67) of Dimmit County indicate wooden, rotted cart wheels could still be observed along portions of this road in southern Texas in the 1 ate 19 th and early 20 th century.

Following Ziviey's historical work, it was not until the 1960 s that archaeological work was conducted in the vicinity of the Light Ranch. In 1965, members of the Carrizo High School archaeological group conducted a field trip to the (then) George Light Ranch (Laxson 1965:1-14). Preliminary 
surface surveys were conducted in the northeastern portion of the ranch, and 50 dart and arrow points were collected. These included Ensor, Perdiz, Carrizo, Scal1 orn, Toyah, and nonstemmed, convex-based points such as Catan and Abasolo. Triangular points, Ensors and convex-based points dominated the artifact collection, and arrow points were observed on $7 y$ infrequent $1 y$.

At approximately the same time, in 1965, a prehistoric burial was reported on the Light Ranch and was 1 ater excavated by personnel from the Witte Museum in San Antonio (notes on file, Witte Museum). The badly decomposed skeletal remains were thought to be that of a child buried in a flexed position. Only portions of the cranium and arm bones were still identifiable. No artifacts were associated with the burial, and on 1 y fragmentary data are currently available. Artifacts collected in the vicinity of the burial are $i 11$ ustrated in Appendix 2.

No further archaeological investigations were conducted in the area until 1982 when archaeologists from the Texas Parks and Wildlife Department visited the study area for a preliminary inspection of proposed fence 1 ines in the northeastern section of the management area property (notes on file, Texas Parks and Wildlife Department, Austin). Eighteen small prehistoric sites were located (none of these are currently located near any proposed pipel ine or seismic routes). The identified sites, along the upland slopes that comprise the watershed for the Sage Creek drainage, were usually characterized by a 1 ight scatter of 1 ithic debris and an occasional stone too1. Collected or observed artifacts included a "turtle-backed scraper" (Clear Fork too1?), a Scallorn arrow point, and triangular bifaces.

Hester (1984) has presented a recent summary of the archaeology as it is known to date in Dimmit County. A previous paper by Nunley and Hester (1966) also reviews the Dimmit County prehistory. Additional unpublished information is on file at the Witte Museum. San Antonio, Texas, and early avocational studies are contained in the Peña Pow-low, the newsletter of the Carrizo Springs High School Archaeology Club, particularly from the 1960s. As Hester (1984) has pointed out, despite the 1 ack of regional professional research, significant contributions were made by this group originally organized by J. W. House. Salvage archaeology of several Indian burials was conducted by the club on the Buckhorn. Farias, and Johnson Ranches of Dimmit County, and published information from their early newsletters is on file at the CAR-UTSA and at the Witte Museum, San Antonio. Other individuals who have an avocational interest in the 1 ocal archaeology are C. M. What ley, Dr. D. M. Brown, and T. C. Hi11, Jr.

A1though not located in Dimmit County, the significant work of Hester (1978a, 1978b) on the Chaparrosa Ranch in neighboring Zavala County and Montgomery's (1978) investigations at the Mariposa site indicates that cultural remains similar to those of the study area are found throughout the area. McGraw and Knepper ( $n_{0} d_{0}$ ) have also conducted extensive surveys in Uvalde and Zavala Counties, and the reader is referred to this data for comments on paleoenvironment and interpretations of site distribution.

Further comments on the archaeology of the Chaparral Wildlife Management Area, formerly a segment of the Light Ranch, are found in the Discussion section of this report. 


\section{SITE DESCRIPTIONS}

Four previously unidentified prehistoric occupation sites were recorded adjacent to or within the proposed seismic and/or pipeline routes (Fig. 1). These sites are thought to represent the remains of brief campsite activities, the location only utilized for a single episode or perhaps several short episodes. Site function, in all cases, is thought to be as auxiliary or temporary campsites. Each site is discussed next, and assessments of site potential are given. None of the four recently recorded sites are recommended for further work.

\section{Site 41 DM 78}

Lecation: Site 41 DM 78 is ca. $125 \mathrm{~m}$ west of the intersection of the proposed seismic 1 ine $A$ and the projected pipeline route $A$ (see Fig. 1 ).

Elevation: $510-520$ feet above mean sea level.

Site Description: The site is ca. 75-100 $\mathrm{m}$ in diameter and represents a prehistoric temporary occupation (short-term campsite; 1 imited evidence of 1 ithic and/or food preparation activities). No chronologically diagnostic materials were observed. The nearest natural water source is the tertiary (dry) drainage of Sage Creek, located ca. $275 \mathrm{~m}$ to the northwest, which eventually drains into the Nueces River.

Soll: A thin layer of aeolian sand overlies a compacted reddish brown clayey material. Some colluvium was noted on slopes. Moderate to extensive erosion was noted across the site area.

Vegetation: Thorny brush, mesquite trees, and tall grasses dominate the vegetation, except for a cleared area along a nearby fence 1 ine.

Environmental Setting: The site is situated on an upland slope overlooking the Sage Creek drainage. The location, today, is regarded as an upland, but may have once been the margins of a larger riparian zone if the drainage was formerly a more reliable water source. Visibility is moderate with erosional gul1ies, some in excess of $20 \mathrm{~cm}$ deep, indicating the extent and density of subsurface cultural materials.

Archaeological Evidence: A 1 ight scatter of 1 ithic debris in a relatively discrete area was noted at the site. Several small burned rock fragments were observed, but no features or diagnostic materials were noted or col 1 ected. One distal arrow point fragment (Fig. 2,b) of an unidentified style was collected. Three sma11 bifacial tool fragments were also recovered (Fig. 2,a,c,d).

Site Discussion: The site appears moderately affected by slope erosion with portions extremely eroded. The 1 ack of extensive cultural materials or cultural stratigraphy in any of the erosional cuts suggests that none exist below the surface of the 1 imited site area. No burned rock clusters were identified either on the surface or within gully exposures. 
This page has been

redacted because it

contains restricted

information. 


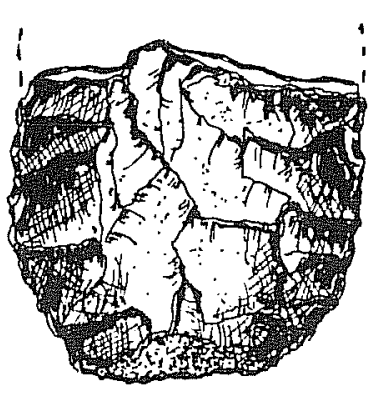

a

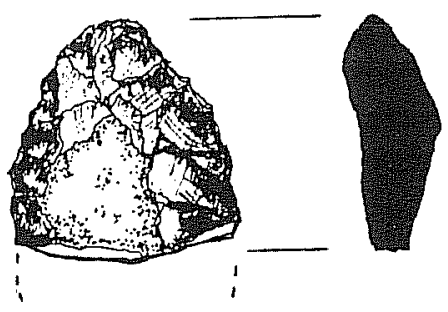

1

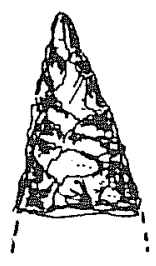

b

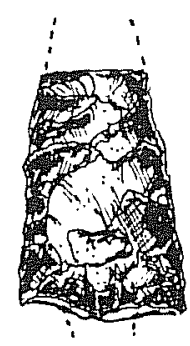

e
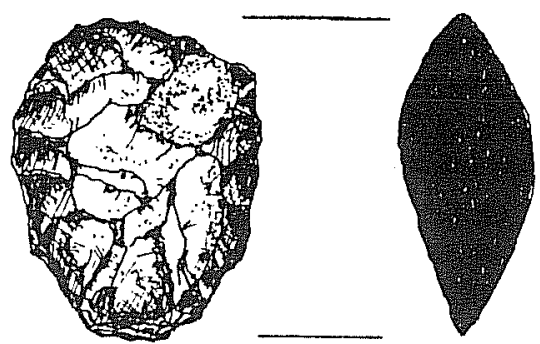

c
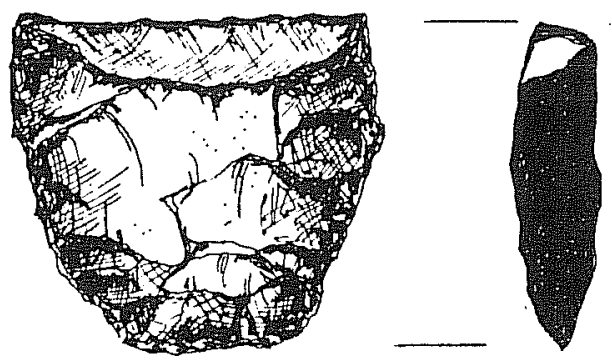

f

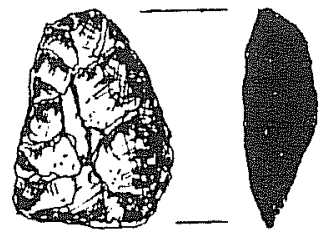

g

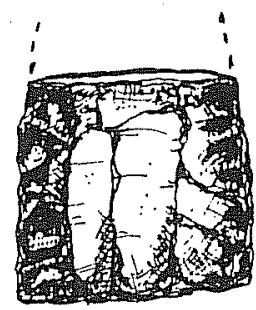

h
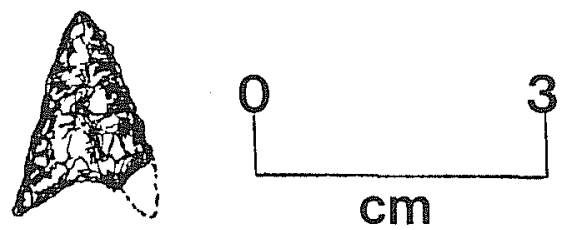

$\mathrm{cm}$

A.Mc Rour. -

Figure 2. Artifacts Recovered from Sites 41 DM 78, 41 DM 79, 41 LS 22, and 41 LS 23. a-d, 41 DM 78; a, thick biface fragment; b, distal arrow point fragment; c, ovate, thick biface; d, distal biface fragment; e-f, 41 DM 79; e, medial section of arrow point; f, distally beveled too1; g, 41 LS 22; smal 1 Late Prehistoric end scraper(?); $h-i, 41$ LS 23; h, alternately beveled biface, proximal end; $i$, Starr arrow point. 
A 25- $m^{2}$ area was collected of 1 ithic debris: recovered were 11 corticate chips, six decorticate chips, five secondary flakes, five tertiary flakes, one expended cobble core, and three small chert core fragments.

Given the limited amount of cultural remains, preliminary interpretations suggest a light to moderate 11 thic reduction (workshop) site with some camping activity as reflected by infrequent observations of small burned rocks. The arrow point and biface fragments suggest Late Archaic to Late Prehistoric activities, and an estimated site age may be ca. A.D. 1000 or later, although this is only the broadest estimate, given the lack of further diagnostic materials, features, or other remains.

Recommendations: As the site area is situated ca. $100 \mathrm{~m}$ west of the projected impact areas of the pipeline route, no further work is recomnended. The lack of significant cultural materials and features, limited site area, and extent of erosion also limits potential for further work at this locale.

\section{SITE 41 DM 79}

Location: Site 41 DM 79 is ca. $600 \mathrm{~m}$ west of the Texas Parks and Wild iffe Department headquarters complex along the seismic line (A) route (see Fig. 1). The extreme margins of the site intersect the surveyed 1ine, and the main site area is belfeved to be $75 \mathrm{~m}$ to over $100 \mathrm{~m}$ south of the 1 ine.

Elevation: $550-560$ feet above ms .

Site Description: The site is ca. 100 by $150 \mathrm{~m}$, and possibly larger (as it extends southwestward away from the seismic line route). The site is defined as a prehistoric light occupation along the upper slopes of a ridge complex adjacent to the tertiary drainage network of Sage Creek. A light scatter of lithic debris and an occasional burned rock characterizes the surface materials. Intensive surveys well in excess of $100 \mathrm{~m}$ from the impacted area indicate that the most concentrated material remains and projected main activity areas of the site are located on a broad, sloping ridge ca. $175 \mathrm{~m}$ south of the proposed seismic line. The amount of burned rock and 11thic debris increases noticeably at this distance from the survey markers. The margins of the site, which intersect the seismic line, are located on extensively eroded slopes adjacent to an ephemeral tributary of Sage Creek. Artifacts observed in this location suggest disturbance by erosional processes. No features, intact or eroded, were noted in the erosional cuts or on the surface.

Soil: Erosion over the site area has revealed a light to moderate scatter of 1ithic debris just below or on the present ground surface. A thin layer of fine-grained light brown unconsolidated sand has generally eroded from the surface to expose a more clayey, compacted reddish brown subsoil 5-15 cm below the present ground surface. Observed cultural materials in the form of Tithic debris are scattered throughout the few upper centimeters of this clayey soil, as observed from numerous and severe erosional cuts in the northeast portion of the site area (adjacent to the marked seismic line). No features or diagnostic artifacts were noted within $75 \mathrm{~m}$ of the projected seismic route. 
legetation: Thorny brush and mesquite trees dominate the local flora; erosion has limited the extent and density of medium grasses across the site area.

Environmental Setting: The site is located along a slightly sloping ridge southwest of a small tertiary drainage of Sage Creek. Prehistoric activities are thought to have been associated with the avallability of a more reliable water source at some time in the past along this same, now dry, drainage.

Archaeological Evidence: A light scatter of lithic debris in the form of corticate and decorticate chips and secondary and tertiary flakes was observed across the site. A few small burned rock fragments were observed in disturbed contexts across the activity area. One medial arrow point fragment (Fig. 2,e) was collected ca. $150 \mathrm{~m}$ south of the proposed seismic 1ine. One other tool, a small distally beveled biface (Fig. 2,f), a Nueces scraper (Turner and Hester 1984:221-222), roughly crescentic (7unate) in shape, was collected ca. $70 \mathrm{~m}$ southeast of the pipeline route. A $25-\mathrm{m}^{2}$ area was collected of lithic debitage in the pipeline route. Nine fragments of debris were collected: one chalcedony burned cobble fragment, two decorticate chips, three secondary flakes (two are burned; all have small, single-faceted platforms), one tertiary flake (single-faceted platform), and two small thick medial biface fragments. All materials collected along the pipeline route appeared to be in a disturbed context due to natural erosion; several large erosional gullies in excess of $13 \mathrm{~cm}$ in depth cut through this area.

Site Discussion: Collected artifacts suggest a 1ight Transitional and/or Late Prehistoric occupational episode similar in intensity and chronological age to site 41 DM 78. The prehistoric activity location appears to be concentrated on the slopes of a large ridge complex ca. $200 \mathrm{~m}$ or more south of the proposed pipeline route. The margins of the site area, characterized by a light scatter of lithic debris and extensive surface erosion, intersect the seismic line route.

Recommendations: No further work is recommended at the area of the marked seismic line, since the concentration of artifactual remains and the possibility of buried deposits are well beyond any impacted range of the seismic line, and the area evidences a paucity of diagnostic or otherwise significant materials.

\section{SITE $41 \quad$ LS 22}

Location: Site 41 LS 22 is located ca. $1.5 \mathrm{~km}$ northwest of the eastern edge of the proposed seismic line (A). The seismic line intersects the northwestern boundaries of the site, and the main concentration of cultural remains lies on the surface of a hilltop ca. $100 \mathrm{~m}$ south of the seismic route. A light scatter of 7 ithic debris is located along the slopes of the hilltop, and this debris becomes noticeably more infrequent as one progresses down the slope.

Elevation: $540-550$ feet above ms 1 .

Site Descriotion: Site 41 LS 22 is ca. $125 \mathrm{~m}$ in diameter. The site represents a temporary occupation, assumed to be Archaic, or possibly Late 
Prehistoric. No chronologically diagnostic materials were recovered. A light to moderate scatter of 1 ithic debris occurs across the $h 111$ mixed with several sma11 burned rock fragments. No features such as burned rock clusters were noted on the surface or as in situ exposures along the numerous erosional gullies which comprise the margins of the site area along the lower slopes. The hilitop site is unique in that no water sources, present or former, were observed with in $300 \mathrm{~m}$ of the location.

Soil: Extensive erosion has taken place in the site area, and natural processes have stripped overlying fine-grained unconsolidated sands from most of the site's surface. A compacted reddish brown clayey subsoil is exposed on most of the surface and throughout the numerous erosional cuts along the slopes. Interestingly. given the light to moderate scatter of 1 ithic debris. very little material was identified in undisturbed contexts along the erosional gullies.

Vegetation: Practicaliy all of the site is overgrown with thorny brush and moderate grasses, although erosion and natural conditions such as a 1 ack of water have limited the extent and density of the 1 atter.

Environmental Setting: The small prehistoric activity area centers around a small hilltop in an upland context. No evidences of a former nearby water source have been identified in the vicinity. Good to moderate ground visibility was noted.

Archaeological Evidence: A 1 ight scatter of 1 ithic debris and an occasiona 1 burned rock comprises the archaeological remains at this site. No features or diagnostic materials were noted or collected. Only four small flakes and chips were noted within ca. $40 \mathrm{~m}$ of the marked survey 1 ine of the proposed seismic route. For a preliminary but clearer estimate of the type and extent of 7 ithic activities at this location, a $25-\mathrm{m}^{2}$ area was collected of a 11 1 ithic debris, located ca. $150 \mathrm{~m}$ south of the seismic 1 ine but near the estimated center of former activities. Fifty-nine fragments of debris were collected. They are as follows:

$\begin{array}{cl}\text { Erequency } & \text { Artifact type } \\ 1 & \text { small uniface } \\ \text { (Fig. 2,g) } \\ 4 & \text { core fragments } \\ 12 & \text { corticate chips } \\ 16 & \text { decorticate chips } \\ 9 & \text { secondary flakes } \\ 17 & \text { tertiary flakes }\end{array}$
Comments
Tength: $2.1 \mathrm{~cm}$, width: $1.5 \mathrm{~cm}$, thickness: $0.75 \mathrm{~cm}$
4 show evidence of edge damage through utilization
3 are utilized along dorsal edges
7 have small, single faceted platforms; the remainder have small multifaceted platforms

Site Discussion: The lithic debris suggests evidence of both tool manufacture and retouch as well as other possibly nonlithic related 
activities, as evidenced by the smal1 uniface. A 1 ack of cores indicates secondary and tertiary 1ithic processes (Hester 1975:213-222).

Recommendations: A1though 41 LS 22 represents a 7 ight to moderate temporary occupation in an upland environmental context, a substantial amount of the site area has been extensively damaged by natural erosional processes. Since on 7y the extreme margins of the site area intersect the proposed seismic 7 ine and artifacts appear in a deflated site context, no further work is recommended at this location.

\section{SITE 41 LS 23}

Location: Site 41 LS 23 is ca. $1 \mathrm{~km}$ west of the eastern 1 imits of the proposed seismic line (A). The site is located on the highest elevation of a sma11 hil1, with 1 ithic debris scattered down slope in a disturbed context. A light scatter of 1 ithic debris was noted within the run-off channels of the erosional gullies.

\section{Elevation: $540-550$ feet above ms 1 .}

Site Description: Site 41 LS 23 is ca. 75-100 $\mathrm{m}$ in diameter. The site represents a (temporary) prehistoric occupation. The location contains the cultural remains of a smal1 occupation and 1 ithic-working center. Comparatively, observed materials were noticeably less frequent at this 1 ocation than at nearby site 41 LS 22 (ca. $500 \mathrm{~m}$ to the northwest). Very 1 itt le burned rock and no features were identified in this locality. A small arrow point was collected on the hilltop ca. $100 \mathrm{~m}$ southwest of the proposed seismic tine (A).

Soil: The surface soil is a compacted reddish brown clayey soi 1 characterized by extreme cracking when dry. Erosional gullies dissect the slopes of the hill. No subsurface cultural materials were noted during inspection of these erosional features. A fine-grained, sandy unconsolidated topsoil common throughout most of the study area is missing from this location and is assumed to have eroded.

Vegetation: The upland chaparral consists of medium grasses, dominated by mesquite trees and thorny brush.

Environmental Setting: Moderate to good visibility was noted along slopes where natural erosion has exposed open areas.

Archaeological Evidence: A 1 ight scatter of 1 ithic debris was observed along the higher elevations of the hilitop ca. $100 \mathrm{~m}$ south of the projected seismic 1ine. A $25-\mathrm{m}^{2}$ area was surface collected along the seismic 1 ine corridor. Four fragments of 1 ithic debris were recovered: two secondary and two tertiary flakes of a light tan-colored chert. A small arrow point and the proximal portion of a smal1 alternately beveled biface were collected ca. 100 $m$ south of the seismic 1 ine area on the hilltop (Fig. 2,h,i). The small arrow point, identified as Starr (Turner and Hester 1985:190), is found both in and south of the 1 ower Rio Grande Valley of southern Texas as well as extending along the coast to near Oso Creek. It has also been reported in 
Tamaulipas, Veracruz, and San Luis Potosi, Mexico. The measurements of this specimen is as follows: length, $1.9 \mathrm{~cm}$; width, $1.5 \mathrm{~cm}$ (Incomplete); thickness, $0.2 \mathrm{~cm}$. The alternately beveled biface fragment was manufactured from a medium gray, fine-grained chert, although much of this coloration may be due to burning as a sma 11 potlid was noted along the distal fracture. The artifact is $2.5 \mathrm{~cm}$ in width and $0.85 \mathrm{~cm}$ thick. The unstemmed, straight-based biface has been basally thinned by multiple soft-hammer percussion flaking.

Site Discussion: Very 1 ittle artifactual evidence of site activities was noted within $50 \mathrm{~m}$ of the proposed seismic 1 ine (as noted in the paucity of the $25-\mathrm{m}^{2}$ area surface collection). The activity area of this Late Prehistoric temporary occupation occurs on the highest elevation of a smal1 hilltop $100 \mathrm{~m}$ to $125 \mathrm{~m}$ southwest of the projected seismic 1 ine (A). Extensive erosion along the slopes of the hill did not reveal any significant cultural deposits to depths of $\mathrm{ca}_{0} 20 \mathrm{~cm}$.

Recommendations: No further work is recommended at this site as no significant cultural resources were found after intensive surveys; col lection analysis, and examination of erosional cuts for possible subsurface deposits.

\section{DISCUSSION}

Preliminary interpretations suggest the sites located in the current study area represent a sample of temporary multifunctional campsites often related to the Late Prehistoric period, as evidenced by arrow point fragments collected from three of the four recorded sites. Disturbances on these sites, in the form of natural erosion, 1 imit an accurate estimate for activity episodes or the possibility of recurring occupations. Given the 1 imited amount of cultural materials present, it is assumed these sites reflect only single or very temporary multiple occupation episodes.

The site interpretations, which suggest a Late Prehistoric emphasis, contrast somewhat with earlier observations by Laxson (1965) where Late Archaic materials dominated the artifact collections of the area. Laxson (1965) surveyed adjacent ranch properties to the current study area, centered around San Roque Creek, several miles to the west. The current study area. containing a series of relatively small upland and/or overlook sites near or adjacent to Sage Creek, contrasts strongly with the extensive occupation zone of San Roque Creek identified by Laxson and excavated later by the Witte Museum in 1965.

The terraces along San Roque Creek just northwest of the management area are thought to represent the margins of an ancient river channel, given the extremely broad floodplain (over $3 \mathrm{~km}$ in width) northward to the present channel of the Nueces River, ca. $12.5 \mathrm{~km}$. The intensity and diversity of this occupation zone reflect a long span of occupations postulated to have existed on the margins of a former confluence point of the Nueces River and an older channel of San Roque Creek. This area would have been a favorable natural setting for occupational sites. Laxson's (1965) comments on the infrequent collection of Late Prehistoric arrow points and the predominance of Archaic materials may be interpreted as recognizing a major hydrological shift of the Nueces River in this area prior to the Late Prehistoric cultural 
period. A rechannelization of the river course, the cutting of an oxbow, for example, to near its present configuration would have precipitated huntergatherer occupational shifts slowly northward, toward more favorable locations, perhaps northward toward the present confluence point.

The frequency of arrow point fragments collected at the sites recorded during this survey may also be related to the observations made by McGraw and Knepper (n.d.) during their studies along portions of the Nueces River in southern Uvalde County and northern Zavala County. Following their interpretive assessment of 65 archaeological sites as we 11 as other earlier recorded sites, it was postulated that a broad-based subsistence pattern gradually shifted to an increased emphasis on local exploitation of specific resources by the terminal Archaic and early Late Prehistoric cultural periods. This was reflected by the similarity of site distributions and patterns of, for example, Late Archaic sites containing Ensor projectile points and early Late Prehistoric sites containing Scallorn arrow points. It was thought a lack of these diagnostic materials in upland contexts, even as isolated finds, represented an emphasis on riparian resource exploitation. During the latter part of the Late Prehistoric, the distribution of diagnostic indicators such as Perdiz arrow points shifted to some upland contexts, and sites containing this diagnostic artifact were generally more scattered throughout the area; such a pattern may indicate a similar but qualitatively distinct pattern of resource exploitation along the Nueces River and in portions of southern Texas.

A 1 ack of substantive data throughout much of the area precludes further interpretations on the significance of the sites recorded during this survey. While further work in southern Texas is needed to more clearly understand the long and varied time period of the region's prehistory, this discussion has presented a preliminary review of known data and comparisons to illustrate the diversity and complexity of the local archaeological record.

\section{SUMMARY}

Four smal1 prehistoric temporary occupation sites were identified and recorded during current field work. Following intensive surveys, material collections, and interpretations, no further work is recommended. Extensive natural erosion across the site areas, the paucity of observed cultural materials, and the lack of significant cultural materials or features were also factors in these assessments. It should be noted, that should significant cultural features be uncovered during seismic or pipeline constructions, and avoidance is infeasible. Lightning $0 i 1$ Company should contact the appropriate state agencies. 
Campbe1 1, T. N.

1975 The Payaya Indians of Southern Texas. Southern Texas Archaeological Association. Special Publication 1. San Antonio, Texas.

Campbe11, T. N. and T. J. Campbe11

1981 Historic Indian Groups of the Choke Canyon Reservoir and Surrounding Area, Southern Texas. Center for Archaeological Research. The University of Texas at San Antonio, Choke Canyon Series 1.

Council of Texas Archeologists (CTA)

1981 Guidelines for Curation Standards and Procedures. Council of Texas Archeologists. Newsletter 5(2).

Dobie, J.F.

1929 A Vaquero of the Brush Country. Southwest Press, Dallas.

Ha17, G. D., S. L. Black, and C. Graves

1982 Archaeological Investigations at Choke Canyon Reservoir, South Texas: The Phase I Findings. Center for Archaeological Research. The University of Texas at San Antonio, Choke Canyon Series 5.

Hester, T. R.

1975 Chipped Stone Industries on the Rio Grande Plain: Some Prel iminary Observations. The Texas Journal of Science 26(12): 213-222.

1978a Background to the Archaeology of the Chaparrosa Ranch, Southern Texas. Center for Archaeological Research. The University of Texas at San Antonio, Special Report 6(1).

1978b Chipped Stone Industries on the Rio Grande Plain: Some Prel iminary Observations. In Background to the Archaeology of Chaparrosa Ranch, Southern Texas, by T. R. Hester:24-32. Center for Archaeological Research. The University of Texas at San Antonio, Special Report 6(1).

1980a Digging Into South Texas Prehistory. Corona Publishing Company, San Antonio. 
Hester (continued)

1980b A Chronological Overview of Prehistoric Southern and SouthCentral Texas. In Papers on the Prehistory of Northeastern Mexico and Adjacent Texas, edited by J. F. Epstein, T. R. Hester, and C. Graves:119-138. Center for Archaeological Research. The University of Texas at Sar Antonio. Speclal Report 9.

1984 The Prehistory of Dimmit County. In Dimmit County Mesquite Roots, edited by Laura Tidwe11:1-6. Wind River Press, Austin.

Hester, T. R., R. F. Heizer, and J. A. Graham

1975 Field Methods in Archaeology. 6th edition. Mayfield Publishing Company, Palo Alto, California.

Inglis, J.M.

1964 A History of Vegetation on the Rio Grande Plain. Texas Parks and Hidilfe Department, Bulletin 45. Austin.

Laxson, B., editor

1965 Field Trip. The Peña Pow-Wow Newsietter, Carrizo Springs Archaeological Society $4(2)$.

Mallouf, M., R. B. Baskin, and K. Killen

1977 A Predictive Assessment of Cultural Resources in Hidalgo and Willacy Counties, Texas. Texas Historical Comission. Archeological Survey Report 23.

MoGraw, A. J. and V. K. Hindes

1987 Chipped Stone and Adobe: A Cultural Resources Assessment of the Proposed Applewhite Reservoir, Bexar County, Texas. Center for Archaeological Research. The University of Texas at San Antonio, Archaeological Survey Report 163.

MoGraw, A. J. and D. A. Knepper

n.d. The East Chacon Project: 11,000 Years of Prehistory Along the Upper Nueces River, Southern Texas. Center for Archaeological Research. The University of Texas at San Antonio. Archaeological Survey Report 125 (in preparation).

Montgomery, J. L.

1978 The Mariposa Site: A Late Prehistoric Site on the Rio Grande Plain of Texas. Center for Archaeological Research. The University of Texas at San Antonio, Special Report 6(2). 
Nuniey, P. and T. R. Hester

1966 Preliminary Archaeological Investigations in Dimmit County, Texas. The Texas Journal of Science 18(3):233-253.

Sellards, E. H., W. S. Adkins, and F. B. Plummer

1958 The Geology of Texas. Volume 2, Structural and Economic Geology. Bureau of Economic Geology. The University of Texas. Bul 1etin 3041. Austin.

Solis, J. de

1931 The Solis of 1767. Translated by P. Forrestal. Preliminary Study of the Texas Catholic Historical Society 1(6). Austin.

Tidwe11, L., editor

1984 Dimit County Mesquite Roots. Wind River Press, Austin.

Tumlinson, $P$.

1980 Memories of Peter Tumilinson Be11, 1869-1956. Verner B. Be11, author. S. J. T. Printers, Saint Jo, Texas.

Turner, E. S. and T. R. Hester

1985 A Field Guide to Stone Artifacts of Texas Indians. Texas Monthly Press, Inc.s Austin.

Zivley, V.

1916 Field notes and detail map of the Kings Highway from Pendleton's Ferry on the Sabine River to Paso de Francia on the RioGrande. Notes on file, Daughters of the Republic of Texas Research Library, Alamo, San Antonio, Texas. 
APPENDIX 1

SURVEYOR'S NOTES OF THE

EL CAMINO REAL*

\#

A D D

DETAIL MAP

oF

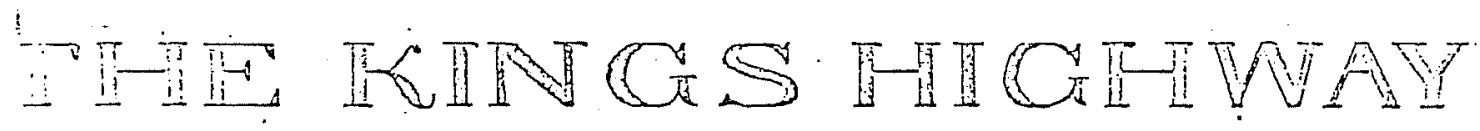

FRON PENDLETON'S FERRY

ONTIIE SABINE RIVTR,

TO PASO DE FRANCIA ON

THE RIO CRANDE.

BY V.N.Zugér, C.E.

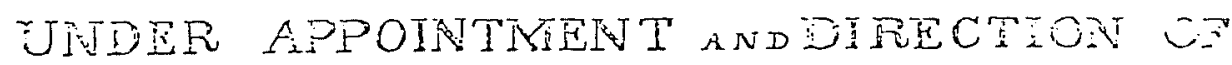

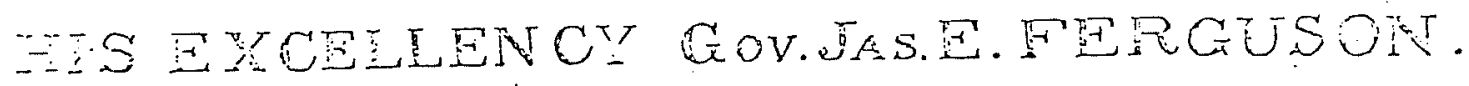

$$
\therefore 2.315-16
$$

*Located in the vicinity of the Light Ranch. Dimmit County, Texas. Taken from V. Zivley's (1916) field notes and detail map of the King's Highway from Pendleton's Ferry on the Sabine River to Paso de Francia on the Rio Grande. On file at the Daughters of the Republ ic of Texas Research Library, Alamo, San Antonio, Texas. 


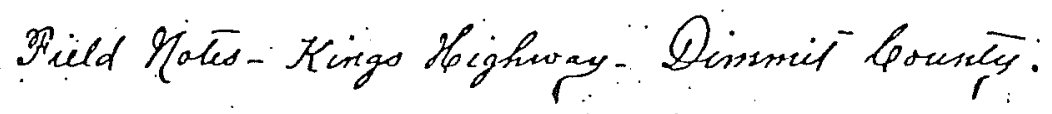

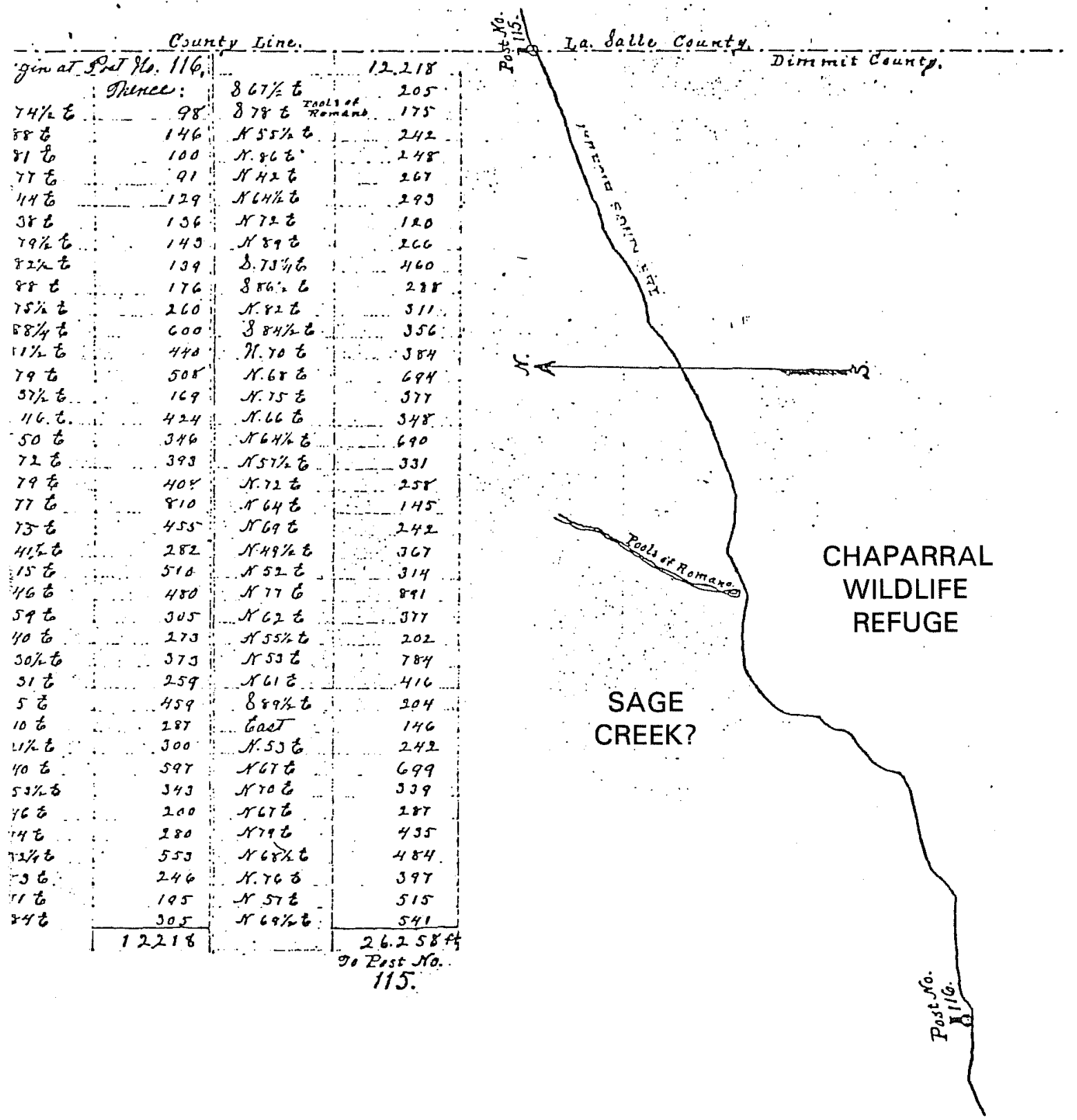


22

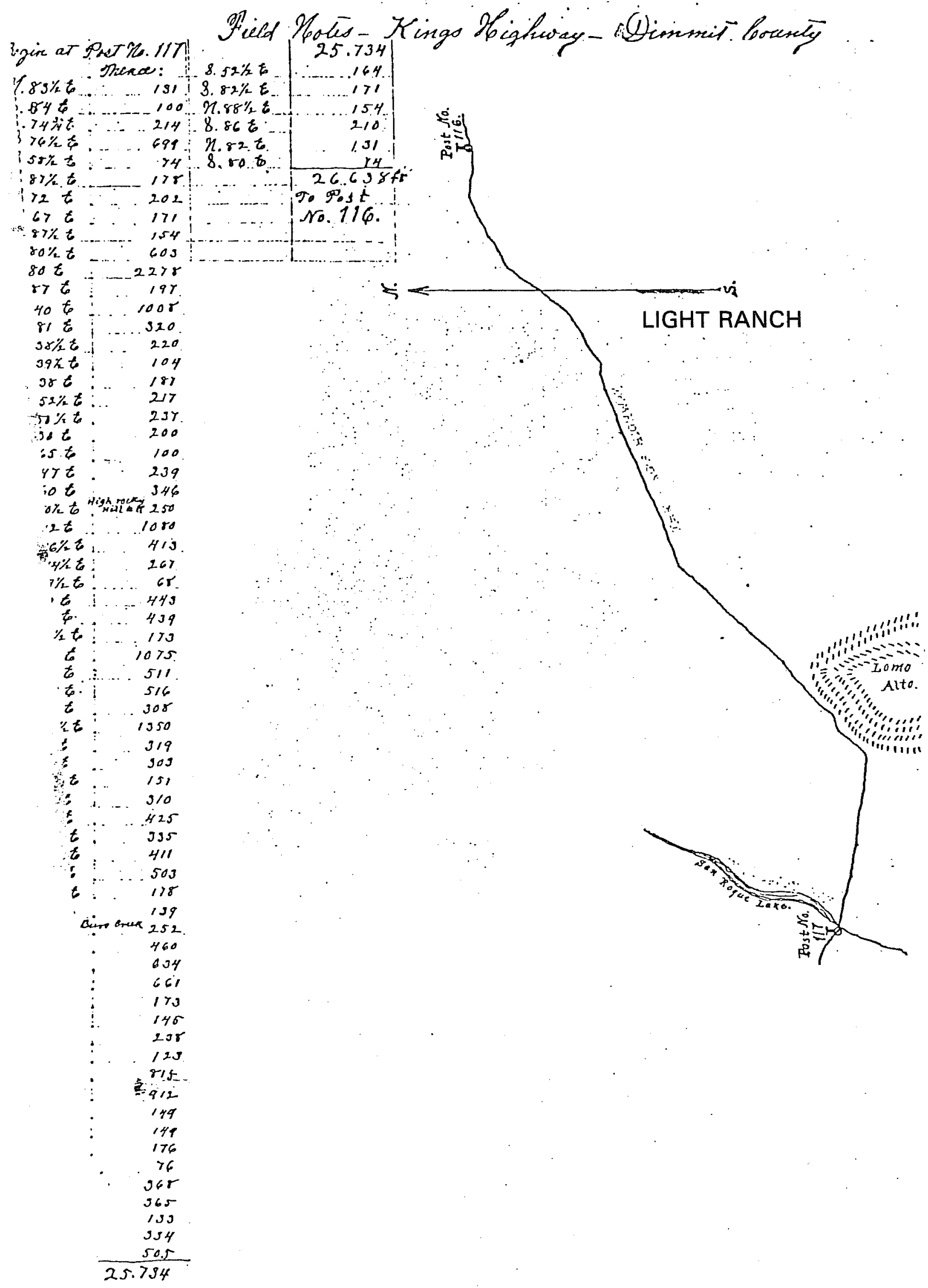




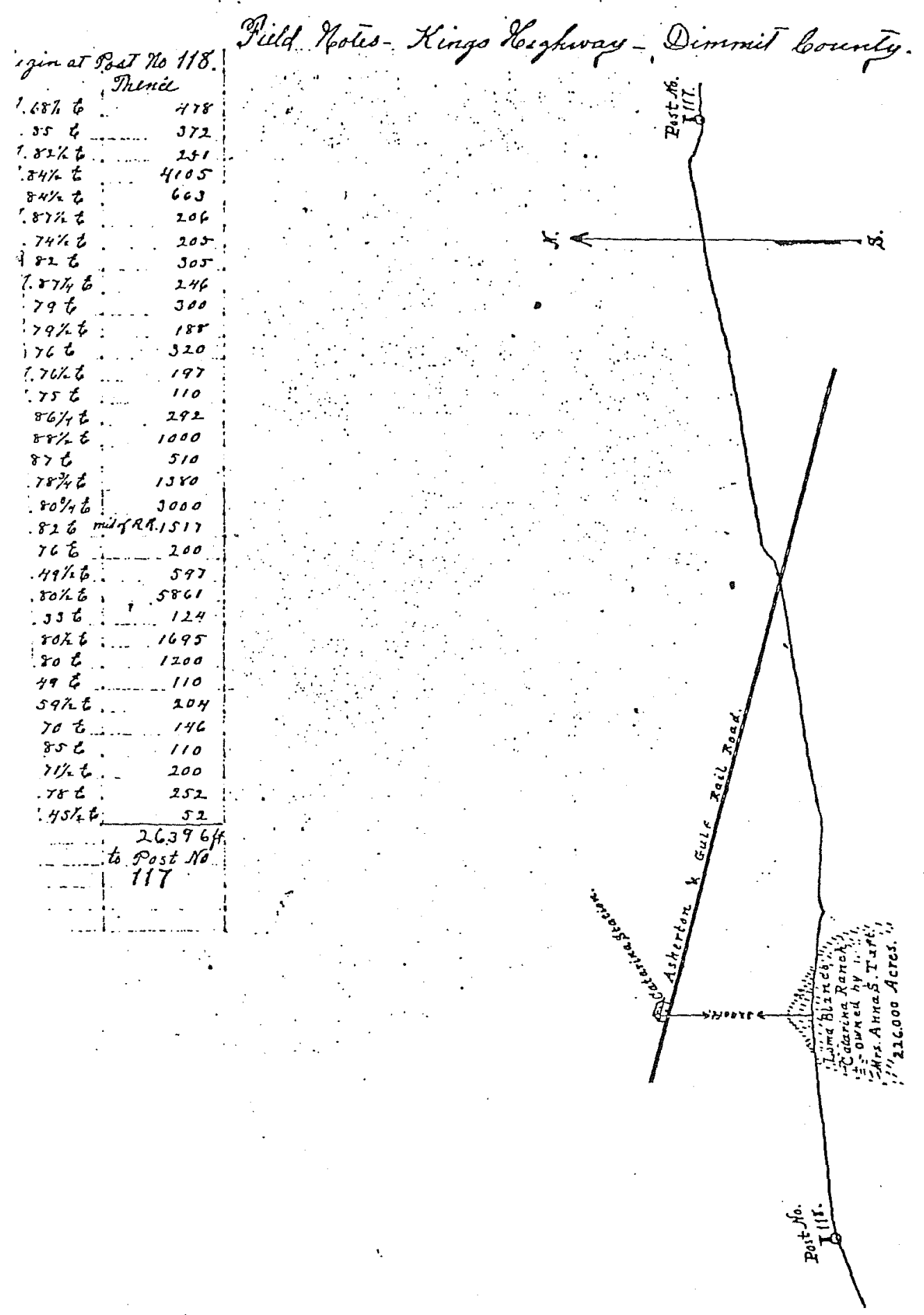


APPENDIX 2

LITHIC ARTIFACTS COLLECTED IN THE VICINITY

OF A PREHISTORIC BURIAL ON THE LIGHT RANCH,

DIMMIT COUNTY, TEXAS

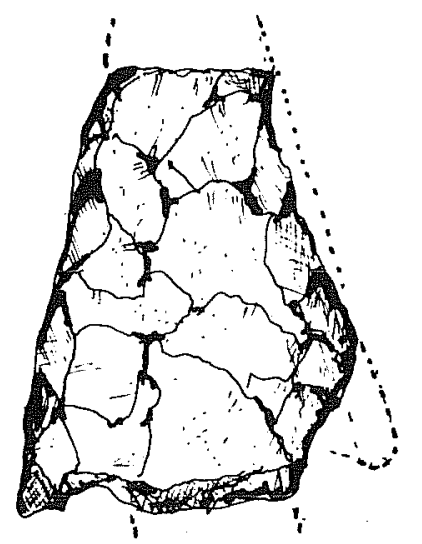

Late Archaic dart point(?)

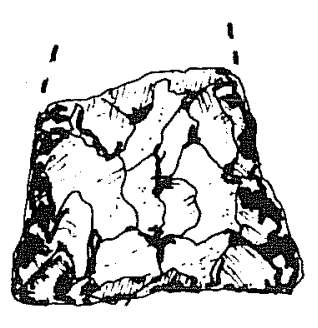

Triangular

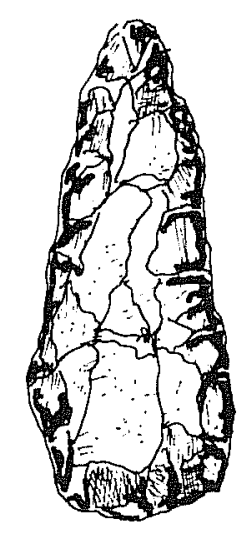

Convex-based Abasolo/Refugio

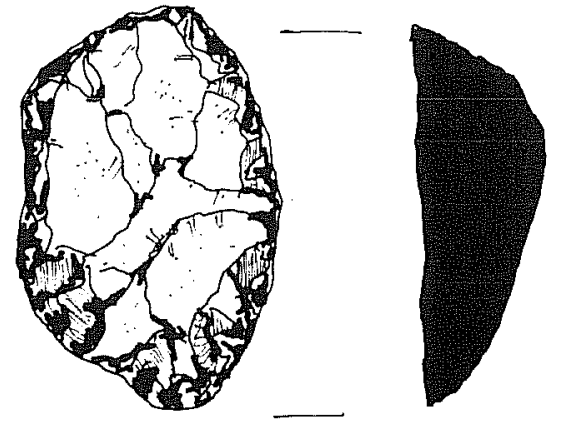

Ovate distally beveled biface

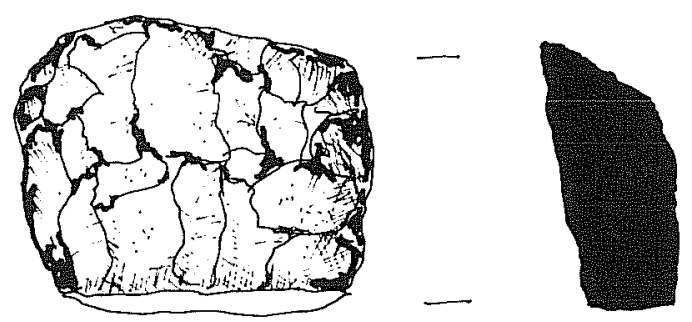

Distally beveled biface (distal fragment)

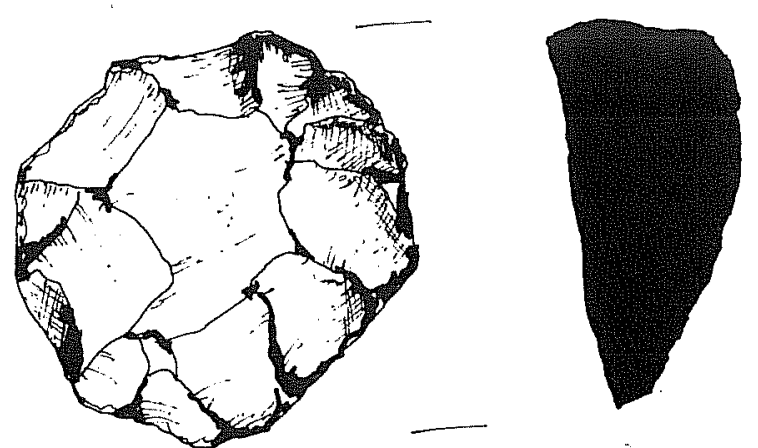

Ovate distally beveled biface

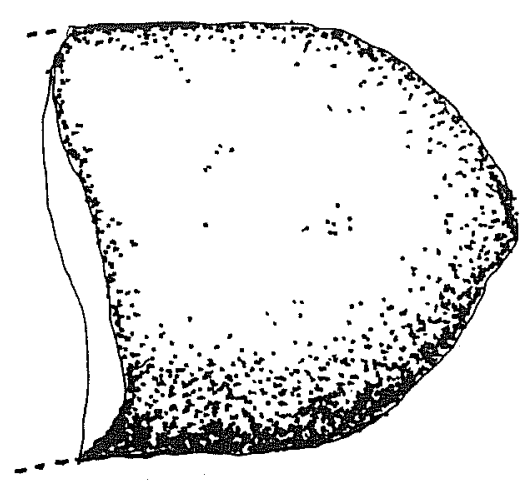

Ground stone fragment

(The artifacts shown here are curated at the Witte Museum, San Antonio, Texas.) 